\title{
Public Administration in the Economic Sphere of Ukraine: Strategic Approach
}

\author{
MYKOLA A. LATYNIN ${ }^{1}$, KATERYNA V. PASTUKH ${ }^{2}$, DENYS L. TARASENKO ${ }^{3}$, \\ SERHII O. SHEVCHENKO ${ }^{4}$, ANNA YU. MUNKO ${ }^{5}$ \\ ${ }^{1}$ Department of Economic Policy and Management, KHARKIV REGIONAL INSTITUTE OF PUBLIC \\ ADMINISTRATION OF THE NATIONAL ACADEMY OF PUBLIC ADMINISTRATION UNDER THE PRESIDENT OF \\ UKRAINE, UKRAINE. E-mail: prof-latynin@tanu.pro \\ ${ }^{2}$ Department of Management and Public Administration, O.M. BEKETOV NATIONAL UNIVERSITY OF URBAN \\ ECONOMY IN KHARKIV, UKRAINE. E-mail: kate.pastukh@tanu.pro \\ ${ }^{3}$ Department of Public Administration, DONETSK STATE UNIVERSITY OF MANAGEMENT, UKRAINE. \\ E-mail: den-tarasenko6537@nuos.pro \\ 4,5 Department of Administration and Management, DNIPROPETROVSK STATE UNIVERSITY OF INTERNAL \\ AFFAIRS, UKRAINE. ${ }^{4}$ E-mail: sshevchenko@tanu.pro; ${ }^{5}$ E-mail: anna.munko@ust-hk.com.cn
}

\begin{abstract}
The introduction of the best modern approaches to public management in the economic sphere is of particular importance for Ukraine. The relevance of the study is determined by the fact that the initiated structural reforms in Ukraine put forward new requirements for public management in the economic sphere. Thus, existing approaches to public management in the economic sphere require transformation. The lack of sufficient scientific justification for improving public management in the economic sphere in modern Ukrainian science indicates the importance of paying attention to this particular problem. The purpose of the study is to develop practical recommendations for improving public management in the economic sphere in Ukraine. In the paper it is proposed to develop a concept of public management strategy in the economic sphere in Ukraine, which takes into account the tasks of increasing the economic independence of regions and territorial communities, supporting their economic development, increasing their economic activities, and ensuring competitiveness in the long term. Attention is also paid to identifying priority areas for improving the state regional policy in the economic sphere; creating conditions and eliminating internal and external threats to the economic development of the country, regions, and territorial communities; improvement of forecasting and policy documents on economic development.
\end{abstract}

Keywords: public management, economic reforms, state regional policy, strategy concept.

JEL Classification: H83, R13, F63. 


\section{Introduction}

The latest trends in public management in the economic sphere in Ukraine increase the attention of Ukrainian society to solving economic problems. The issue of public management modernization in the economic sphere in Ukraine is crucial. Modern economic reforms have not yet yielded the expected result. At the same time, management decisions are already taken point to certain steps to reform public management in the economic sphere in Ukraine under the new challenges and conditions of the present. The current global problems of the world community point to the importance of paying attention to the economic development of countries. Modernization of public management in the economic sphere in Ukraine should contribute to the implementation of changes necessary for the country's economic development. The economic reforms that have begun in Ukraine put forward new requirements for public management in the economic sphere. Attention to reform of public management in the economic sphere is of particular importance.

The Sustainable Development Strategy "Ukraine 2020", within the framework of certain vectors of the movement, provided for the implementation of various important reforms and programs for the development of the state, one of which was the decentralization and reform of public governance. The goal of public governance reform in this strategy is to build a transparent public governance system, ensure the effectiveness of the public service, create a professional institution of the public service, and the result of the implementation of this reform is the creation of an open, effective, transparent, flexible public administration structure using the latest information and communication technologies, capable of implementing public policies aimed at public constant and adequate response to internal and external challenges (Decree of the President..., 2015). The goal of decentralization policy was to move away from a centralized model of governance, build an effective system of territorial organization of power, ensure the possibility of local self-government, implement the provisions of the European Charter of Local Self-Government, the principles of subsidiarity, omnipresence and financial self-sufficiency of local self-government in Ukraine (European Charter of..., 1985).

Modern areas of public governance reform are: ensuring the accountability of public governance bodies (free access to public information, transparency of work, organization of a system of public governance bodies with a clear definition of reporting relationships, the possibility of judicial review of decisions); formulation and coordination of state policy (strategic planning of public policies, quality of legal and regulatory frameworks and public policies, including requirements for the formulation of state policy based on careful study and public participation); modernization of public service and human resources management; provision of administrative services (e-government, standards of provision and guarantees of administrative procedures, quality of administrative services); public financial management (preparation and fulfillment of the state budget, tax administration, public procurement system, external and internal audit, accounting and reporting) (Order of the Cabinet of..., 2016). The tasks of reforming local self-government and the territorial organization of power in Ukraine include: ensuring the accessibility and quality of public services; achieving optimal distribution of powers between executive authorities and local self-government bodies; determining a relevant territorial background for the activities of executive authorities and local self-government bodies to ensure the accessibility and adequate quality of public services by these bodies; creation of appropriate organizational, material and financial conditions to ensure that local self-governments exercise their own and delegated powers (Order of the Cabinet of..., 2014).

Due to change of the paradigm of relations between state authorities, local self-government and society, directions for improving public management in the economic sphere in Ukraine should be set. Owing to the modern challenges and changes in the introduction of the best modern approaches to public management in the economic sphere, it becomes of particular importance. The basis for the further development of public management in the economic sphere in Ukraine should be the proposed directions for its improvement. 


\section{Materials and Methods}

Scientists of various fields of knowledge paid attention to public management in the economic sphere in Ukraine (Kregul and Batrymenko, 2016; Holovko et al., 2020; Bila-Tiunova et al., 2019; Bila Tiunova et al., $2019^{b}$ ). Theoretical and methodological background, peculiarities and mechanisms of public management in the economic sphere were studied. However, many questions regarding the implementation of modern public management in the economic sphere in Ukraine require more detailed consideration. Now in Ukraine, new scientific approaches to public management in the economic sphere are being formed. A wide range of studies is devoted to public management in the economic sphere at the state, regional and local levels, as well as the scientific justification of state regional policy in the economic sphere in Ukraine, the problems of its formation and implementation, the development of practical recommendations for improving its mechanisms.

The strategic development of the country and its regions should be aimed at providing an innovative model of economic growth, creating prerequisites for long-term qualitative changes (Ospanova et al., 2014; Temirbolat et al., 2015; Temirbolat et al., 2016; Temirbolat et al., 2017). The main task of development of the state and its integration into the international space is reduction of interregional differentiation, support and development of available potential of territories, achievement of decent living conditions of citizens. The main guidelines for the development of the regional economic system are the formation of an effective modernized economy at the regional level, the basis of which should be the balancing of the used domestic potential with the flow of external resources, the goal of formation is to strengthen the factors of economic growth and improve the quality of human potential (Abramov, 2016; Latynin et al., 2017; Cheuk et al., 2021; Zeebaree et al., 2021; García-Zambrano et al., 2020; Kostruba, 2017; Kostruba, 2018).

The lack of sufficient scientific justification for improving public management in the economic sphere in modern Ukrainian science indicates the importance of paying attention to this particular problem. The aim of the study is to develop practical recommendations for improving public management in the economic sphere in Ukraine. Objectives of the study are to analyze the implementation of modern public management in the economic sphere in Ukraine and to determine the directions for improving public management in the economic sphere in Ukraine.

The methodological basis of the article was a dialectical approach to the consideration of public administration in the economic sphere of Ukraine. The dialectical approach to the analysis of public management in the Ukrainian economy is characterized by three main principles: 1) the principle of historicism, which includes the study of genesis and retrospective analysis of the subject of study; 2) the principle of general connection, which seeks to understand the essence by identifying the diversity of its external and internal connections, as well as clarifying the causal links; 3 ) the principle of contradiction, which is based on the method of system analysis.

The dialectical approach includes such general scientific methods as analysis and synthesis. In particular, these methods, as well as the method of collecting relevant information were used in the study of Ukrainian laws and regulations to identify priority areas for improvement of state regional policy in the economic sphere and the development of the concept of public administration strategy.

\section{Results and Discussion}

Due to the current global challenges in Ukraine, there is an increase in the responsibility of public authorities for the successful implementation of economic reforms at the state, regional and local levels. One of the main prerequisites of democratic governance based on the rule of law is an effective system of public governance. If there is an efficient, professional, effective and regulated system of central executive bodies, the government can work effectively to reform various areas of state policy (Order of the Cabinet of..., 2016). The implementation of state regional economic policy in Ukraine is ensured by the President of Ukraine, the Verkhovna Rada of Ukraine, the Cabinet of Ministers of Ukraine, central and local executive bodies, and local self-government bodies. 
According to the Constitution of Ukraine (1996), the President of Ukraine adresses to the nation and the Verkhovna Rada of Ukraine with annual and extraordinary affairs on the internal and external situation of Ukraine, which are taken into account in the development of documents on state regional policy of Ukraine in various areas. Defining the foundations of domestic and foreign policy; approval of the state budget of Ukraine, amendments to it, monitoring of its implementation, as well as the adoption of a decision on the performance report of the state budget of Ukraine is ensured by the Verkhovna Rada of Ukraine. The Cabinet of Ministers of Ukraine develops and implements national programs of social, economic, scientific, technical and cultural development of Ukraine, and the Verkhovna Rada of Ukraine approves them. Implementation of investment, financial, price and tax policies; labour and employment policies, social protection, education, science and culture, nature protection, environmental safety and environmental management policies are provided by the Cabinet of Ministers of Ukraine. He also organizes and ensures the implementation of foreign economic activity of Ukraine; ensures equal conditions for the development of all forms of ownership; administers public property; develops a draft law on the state budget of Ukraine, ensures the implementation of the approved budget and submits a report on its implementation (Constitution of Ukraine..., 1996).

The main tasks of ministries as central executive bodies, which ensure the implementation of state policy in various areas, are: determining priority areas of development; provision of legal and regulatory framework; summarizing the practice of applying legislation, developing proposals for its improvement and submitting, in accordance with the established procedure, draft regulatory legal acts for consideration by the President of Ukraine and the Cabinet of Ministers of Ukraine; to inform and explain the implementation of state policies in different spferes; ensuring social dialogue at the sectoral level. The main tasks of other central executive bodies, such as services, inspections, agencies and commissions, include: management of state property; government supervision (monitoring); provision of administrative services; submission of suggestions for state policy-making provision to ministers who direct and coordinate their activities (Law of Ukraine of..., 2011).

The Ministry for Development of Economy, Trade and Agriculture of Ukraine (Reform of state procurement..., 2020) is the main body in the system of central executive bodies that ensures the formation and implementation of state policy in the economic sphere in Ukraine. Its main tasks include ensuring the formation and implementation of state policies for economic and social development; state entrepreneurship development policy; state investment policy; state pricing policy; state innovation policies in the real sector of the economy; state industrial policy; state policy in the sphere of intellectual property; state agrarian policy, state policy in the area of agriculture and agrarian business; state policy in the area of technical regulation, standardization, metrology and metrological activities; state and public procurement policies; state order for training of specialists, scientific, academic personnel and staff, skills development and retraining of personnel; state policy in the sphere of state property management; public-private partnership policies; state policy on the establishment and functioning of industrial parks; state tourism and resorts policy; state policy in the sphere of state market supervision; state policies in trade and personal services; state policy on Ukraine's economic and social cooperation with the European Union; a unified foreign economic policy, a policy of integrating the national economy into the world economy, cooperation with the World Trade Organization; state policies to attract international technical assistance; state policy in the sphere of labor, employment of population, labor migration, employment relations, social dialogue; state military-industrial policy; ensuring the formation and implementation of state policies in the sphere of state export control; in the sphere of state material reserve; in the field of official statistics; in the field of fisheries and industry, protection and management of aquatic bioresources, regulation of fishing and safety of navigation of vessels of the fleet of fisheries, forestry and hunting, veterinary medicine, safety and certain indicators of food quality, in the field of quarantine and plant protection, in the field of geodetic and cartographic activities, land relations, land management, in the field of state land cadastre, state supervision (control) in the agro-industrial complex; in the field of industrial safety, labor protection, occupational health, treatment of explosive materials, implementation of the state mining and state supervision and control of observance of requirements 
of the legislation on labor and employment of the population; ensuring the formation of state regulatory policy, state policy on licensing, permitting system, supervision (control) in the field of economic activity; state price control policy; state consumer protection policy; state policy in the field of supervision (control) in the system of engineering and technical support of the agro-industrial complex; participation in the formation and implementation of public policy in the provision of administrative services; implementation of state policy in the field of organization and control over production of strict accounting documents, securities (Regulations on the... 2019).

Implementation of state and regional socio-economic and cultural development programmes and environmental protection programmes; preparation and implementation of regional and district budgets; report on the implementation of budgets and programmes; interaction with local selfgovernment bodies is provided by local state administrations, which exercise executive power in regions and districts, cities of Kyiv and Sevastopol (Law of Ukraine.., 1999). Local self-government bodies approve programmes for the socio-economic and cultural development of regions and districts and monitor the implementation of such programmes; approve regional and district budgets, which are formed from the state budget for their appropriate distribution among the territorial communities or for the implementation of common projects and from funds engaged on a contractual basis from local budgets for the implementation of socio-economic and cultural programs, and monitor their implementation. Territorial communities of the city, village, settlement manage the assets which are in municipal property; approve and monitor socio-economic and cultural development programmes; approve the budgets of the relevant administrative-territorial units and monitor their implementation; establish local taxes and fees; ensure the conducting of local referendums and the implementation of their results; create organizations, institutions, utilities, as well as reorganize, exercise control over their activities and liquidate (Law of Ukraine of..., 2011).

The latest trends in public management in the economic sphere in Ukraine increase the attention of Ukrainian society to solving economic problems. The issue of public management modernization in the economic sphere in Ukraine is crucial. The Strategy of Public Management Reform of Ukraine for the 2021 (Public administration reform..., 2018) states that one of the main prerequisites of democratic governance based on the principles of the rule of law is an effective system of public governance. If there is an efficient, professional, effective and accountable system of central executive authorities, the government can effectively formulate public policies in various areas. Ensuring the legitimacy, predictability of administrative actions, reducing the administrative load of state regulation, improving the quality of administrative services will increase the state's position in international competitiveness ratings. The objective of this strategy is to improve the public governance system and the competitiveness of the country, and the result of its implementation is an effective and accountable public governance system, which should ensure the sustainable development of the country, serve the interests of society and provide high-quality services (Order of the Cabinet of..., 2016).

The purpose of the Concept of Reform of Local Self-Government and Territorial Organization of Power in Ukraine is to determine the directions, mechanisms and deadlines for the formation of effective local self-government and territorial organization of power in order to create and maintain a full living environment for citizens, establish institutions of direct people's rule, satisfy the interests of citizens in the spheres of life, provide quality accessible public services, and coordinate the interests of the state and territorial communities. One of the expected results of implementation are: economic, social development of regions and territorial communities; stimulating the economic development of the territories; strengthening the organizational, legal and material capacity of territorial communities and local self-government bodies; accessibility and quality of public services (Order of the Cabinet of Ministers, 2014).

An analysis of the implementation of modern public management in the economic sphere in Ukraine proves that despite certain steps to reform it, the objective need is to improve public management in the economic sphere in Ukraine (Public Administration Reform..., 2017). Taking into account the foreign experience of public management in the economic sphere is extremely important at the present stage of the development of Ukraine. Focus on Polish experience will contribute to the 
modernization of public management in the economic sphere in Ukraine. The experience of reforming public management in the economic sphere in Poland is partially used in Ukraine. Representatives of state authorities and local self-government seek to adapt the Polish experience to Ukrainian realities. However, insufficient attention has been paid to the strategic approach to public management in the economic sphere. An example for both Ukraine and other countries of the world is that due to a strategic approach to public management in the economic sphere the conditions for the development of the country were created in Poland.

The interesting fact is that Poland receives funding from the Structural Funds and the Cohesion Fund in the form of pre-financing, interim payments, and final balance payments. The funds transferred to Poland by the European Commission constitute the budget of European funds. The budget is used to finance expenditures, within the framework of projects, for the part to be reimbursed from the funds of the European Union. Budget revenues and expenditures are not taken into account in the process of calculating the state budget deficit. The bank transfers funding from European Union funds to beneficiaries. Payments are made based on a payment order submitted to the institution with which the beneficiary agreed. Part of the project financing comes not from the budget of European funds, but, for example, from the state budget or the budget of regional authorities, transferred to the beneficiary in the form of special grants by the relevant institution (Cohesion Policy..., 2015). In the current circumstances, the experience of modern public management in the economic sphere in Poland can be partially used in Ukraine.

World practice shows that the renewal of regional governance and regional economic policies in the context of globalization and integration should be based on new forms of interaction while transforming weaknesses into opportunities, mobilizing the region's potential for development, neutralizing conflicts of interest with general constructive cooperation forming a system of regional institutions for attracting investment and disseminating innovation (Latynin et al., 2017). To date, it is relevant to develop tools to maximize the approximation of the activities of public authorities to a balanced state of implementation of public management strategies and actions, to eliminate errors to ensure transparency of public management in possible ways (Romanenko, 2016), to pay attention to the training of highly qualified specialists who could implement the functions of public management (Nepomnyashchyy et al., 2019; Mishchuk et al., 2020; Andreiev et al., 2019; Bukhtiarova et al., 2019; Atabekova, 2019; Atabekova, 2020). One of the directions of improving public management in the economic sphere in Ukraine may be the development of a concept of a public management strategy in the economic sphere in Ukraine, the implementation of which will contribute to the success of the modern economic reforms initiated. The creation of such a strategy concept should aim at introducing an effective public management mechanism in the economic sphere, which should be integrated.

As part of the development of the concept of public management strategy in the economic sphere in Ukraine, should be defined tasks to increase the economic independence of regions and territorial communities, for supporting their economic development, intensify economic activity in regions and territorial communities, and ensure the competitiveness of regions and territorial communities in the long term. The identification of priorities for improving state and regional economic policies, as well as creating conditions and eliminating internal and external threats to the economic development of the country, including regions and territorial communities; and also improvement of forecasting and policy documents on economic development is particularly important. Such activities require fundamental changes in approaches to the strategic development of regions and territorial communities. The strategy of public management in the economic sphere in Ukraine should include, first of all, the definition of a mission, which will consist in the formation of effective public management in the economic sphere and the introduction of its integrated mechanism. The strategic goal of public management in the economic sphere in Ukraine should be the building an effective system of public management in the economic sphere, which should ensure the economic development of the country through systematic, integrated, innovative approaches and aimed at satisfying the interests of all citizens of the country. 


\section{Conclusion}

An analysis of the implementation of modern public management in the economic sphere proved that despite certain steps to reform it, the objective need is to improve public management in the economic sphere in Ukraine. Due to modern global challenges, the responsibility of public authorities for the successful implementation of economic reforms is increasing. Objectively, there is a need to improve public management in the economic sphere in Ukraine. Taking into account the foreign experience of public management in the economic sphere is extremely important at the present stage. Focus on Polish experience will contribute to the modernization of public management in the economic sphere in Ukraine.

The development of the concept of public management strategy in the economic sphere in Ukraine is of particular importance, as its implementation will contribute to the success of the modern economic reforms initiated. The basis for restoring economic growth in Ukraine should be regions and territorial communities, the path to prosperity of the country - increasing the economic independence of regions and its territorial communities, supporting their economic development, creating prerequisites for qualitative transformations, intensifying economic activities in regions and territorial communities, ensuring the competitiveness of regions and territorial communities in the long term.

\section{References}

1. Abramov, R.A. (2016). Regional economic policy based on industrial sector clustering in the context of sustainable development. Research Journal of Pharmaceutical, Biological and Chemical Sciences, $7(2), 2100-6$.

2. Andreiev, S., Kogutiuk, V., Dymenko, R., \& Fediunin, S. (2019). Problems of development of interdisciplinary field of knowledge "public administration and management" in Ukraine. International Journal of Innovative Technology and Exploring Engineering, 8(7), 2642-51.

3. Atabekova, A. (2019). Technology-facilitated harm to individuals and society: Cases of minor's selfproduced sexual content in Russia. Journal of Critical Reviews, 6(6), 410-5.

4. Atabekova, A. (2020). University discourse to foster youth's sustainability in society amidst COVID19: International and Russian Features. Sustainability (Switzerland), 12(18), 2463.

5. Bila-Tiunova, L., Bilous-Osin, T., Kozachuk, D., \& Vasylkivska, V. (2019ª). Participation of civil society in public administration: prospects for international experience implementation in Ukraine. Humanities \& Social Sciences Reviews, 7, 757-64.

6. Bila-Tiunova, L., Neugodnikov, A., \& Danylenko, Yu. $\left(2019^{\mathrm{b}}\right)$. The problems of public administration in the sphere of healthcare in Ukraine. International Journal of Applied Exercise Physiology, 8(2), 516-23.

7. Bukhtiarova, A., Dukhno, Y., Kulish, G., Kurochkina, I., \& Lypchanskyi, V. (2019). Ensuring transparency of key public finance authorities. Investment Management and Financial Innovations, 16(2), 128-39.

8. Cheuk, S., Phua, L. K., Siti-Nabiha, A. K., Sahari, S., Nichol, E. O., \& Tinggi, M. (2021). Financial management capacity, accountability, own income generation, revenue diversification and financial sustainability in charities of Malaysia. Estudios De Economia Aplicada, 39(1), 1-18.

9. Cohesion Policy 2014-2020 in Poland (Partnership Agreement and operational programmes). (2015). Main aspects of the implementation system http://www.cohesify.eu/wpcontent/uploads/2018/06/PL_Podkarpackie.pdf [Accessed Feb 12, 2021].

10.Constitution of Ukraine. (1996) https://zakon.rada.gov.ua/laws/show/254к/96-вp\#Text [Accessed Feb 12, 2021].

11.Decree of the President of Ukraine of 12 January 2015 No.5. (2015).“On the Ukraine 2020 Sustainable Development Strategy" https://zakon.rada.gov.ua/laws/show/5/2015\#Text [Accessed Feb 12, 2021].

12.European Charter of Local Self-Government. (1985). https://zakon.rada.gov.ua/laws/show/994_036\#Text [Accessed Feb 12, 2021]. 
13.García-Zambrano, L., Rodríguez-Castellanos, A., \& García-Merino, J. D. (2020). Management of firms' intangibles and their impact on sustainable financial performance. Estudios De Economia Aplicada, 32(3), 1117-32.

14.Holovko, K., Levchenko, S., \& Dubinskiy, O. (2020). Subjects of public administration: reforming the concept in Ukraine. Baltic Journal of Economic Studies, 6(1), 35-41.

15. Kostruba, A.V. (2017). Occurrence of resolutive condition of a deed as a juridical fact in civil law of Ukraine. Journal of Advanced Research in Law and Economics, 8(3), 857-64.

16. Kostruba, A.V. (2018). Law enforcement as a form of realization of right: Phenomenological analysis experience (Civilized aspect). Revista de Derecho Civil, 5(1), 177-90.

17.Kregul, Yu., \& Batrymenko, V. (2016). Reform of local self-government in Ukraine. Foreign Trade: Economy, Finances, Law, 1, 17-26.

18.Latynin, M.A., Maistro, S.V., \& Stativka, N.V. (2017). State economic policy of regional development. Kharkiv: Mahistr.

19.Law of Ukraine of March 17, 2011 No. 3166-VI. (2011). "On central executive bodies" https://zakon.rada.gov.ua/laws/show/3166-17\#Text [Accessed Feb 12, 2021].

20.Law of Ukraine. (1999). "On local state administrations" of April 9, 1999 No. 586-XIV https://zakon.rada.gov.ua/laws/show/586-14\#Text [Accessed Feb 12, 2021].

21.Mishchuk, H., Bilan, S., Yurchyk, H., Akimova, L., \& Navickas, M. (2020). Impact of the shadow economy on social safety: the experience of Ukraine. Economics and Sociology, 13(2), 289-303.

22.Nepomnyashchyy, O., Medvedchuk, O., \& Lahunova, I. (2019). Legal regulation of conformity assessment of personnel qualification in construction. Asia Life Sciences, 21(2), 405-14.

23. Order of the Cabinet of Ministers of Ukraine of June 22, 2016 No. 474-r. (2016). "Strategy of public administration reform in Ukraine until 2021" https://zakon.rada.gov.ua/laws/show/474-2016p\#Text [Accessed Feb 12, 2021].

24.Order of the Cabinet of the Ministers Ukraine of April 1, 2014 No. 333-p. (2014). “On approval of the Concept of reforming the monthly self-government and territorial organization of power in Ukraine" https://zakon.rada.gov.ua/laws/show/333-2014-p\#Text [Accessed Feb 12, 2021].

25.Order of the Cabinet of the Ministers Ukraine of April 1, 2014 No. 333-p. (2014). "On approval of the Concept of reforming the monthly self-government and territorial organization of power in Ukraine" https://zakon.rada.gov.ua/laws/show/333-2014-p\#Text [Accessed Feb 12, 2021].

26.Ospanova, A., Temirbolat, A., Abdikulova, R., Mekebaeva, L., Kalkabaeva, S., \& Ospanova, A. (2014). The idea of Turkic unity in Kazakh poetry of the early twentieth century. Life Science Journal, 11(8), 207-11.

27.Public administration reform strategy of Ukraine through 2021. (2018) https://www.kmu.gov.ua/storage/app/sites/1/reform\%20office/01_strategy_eng.pdf [Accessed Feb 12, 2021].

28.Public Administration Reform. (2017). Report on Implementation of the 2016-2020 Strategy of Public Administration Reform in Ukraine in 2016-2017 https://www.kmu.gov.ua/storage/app/media/reform\%20office/PAR\%20annual\%20report_Eng.pd $f$ [Accessed Feb 12, 2021].

29.Reform of state procurement. (2020). Official website of the Ministry for Development of Economy, Trade and Agriculture of Ukraine https://www.me.gov.ua/Documents/Detail?lang=enGB\&id=4f2cb072-bac6-4ded-b564-5a00dd24511a\&title=ReformOfStateProcurement [Accessed Feb 12, 2021].

30.Regulations on the Ministry of Development of Economy. (2019). Trade and Agriculture of Ukraine: Resolution of the Cabinet of Ministers of Ukraine of 11.09. 2019 No. 459 https://zakon.rada.gov.ua/laws/show/838-2019-n\#Text [Accessed Feb 12, 2021].

31.Romanenko, Y.O. (2016). Place and role of communication in public policy. Actual Problems of Economics, 176(2), 25-31.

32.Temirbolat, A.B., Abdikulova, R.M., Kalkabaeva, S.A., Ospanova, A.A., \& Ospanova, A.A. (2015). Transformation of Novel's genre in modern literature. Mediterranean Journal of Social Sciences, 6(4S2), 333-9. 
33.Temirbolat, A.B., Daribaev, S.D., Imakhanbet, R.S., Ospanova, A.A., \& Ospanova, A.A. (2016). Influence of mass literature on the reader's consciousness. Global Media Journal, 2016, 1-6.

34.Temirbolat, A.B., Imakhanbet, R.S., Orda, G.Z., Ospanova, A.A., \& Omarov, T.K. (2017). Specifics of embodiment of the national idea in Kazakh literature. Man in India, 97(20), 435-45.

35.Zeebaree, M., Sattar, S., Ismael, G. Y., Qader, A. N., \& Aqel, M. (2021). Impact of infrastructure barriers on electronic government implementation. Estudios De Economia Aplicada, 38(4), 3971. 